\title{
Major Determinants that Influence the Choice of Brand of Mobile Phone
}

\author{
Frank B. K. Twenefour \\ Department of Mathematics, Statistics and Actuarial Science, Takoradi Technical University, Takoradi, Ghana \\ Email: frank.twenefour@ttu.edu.gh
}

How to cite this paper: Twenefour, F.B.K. (2017) Major Determinants that Influence the Choice of Brand of Mobile Phone. Open Journal of Statistics, 7, 663-675. https://doi.org/10.4236/ojs.2017.74046

Received: July 5, 2017

Accepted: August 14, 2017

Published: August 17, 2017

Copyright $\odot 2017$ by author and Scientific Research Publishing Inc. This work is licensed under the Creative Commons Attribution International License (CC BY 4.0).

http://creativecommons.org/licenses/by/4.0/

\begin{abstract}
The study examines whether there is an association between brand of mobile phone used and occupational status, educational level and satisfaction level. Influence of mobile phone usage was also examined. Data were collected on 478 mobile phone users. Convenient sampling method where the respondents were interviewed as they were encountered was used. Statistical analysis methods such as descriptive statistics, chi-square test statistic, one sample t-test, were applied. The study indicated that Samsung is the most used mobile phone brand. The study also revealed that the major factors that influence the choice of a brand of mobile phone are price, the number of features, battery capacity, quality and fashionableness. The study discovered that there is no association between mobile phone brand used and educational level. The study reveals that there is an association between brand of mobile phone used and satisfaction with performance. Conclusion can be drawn that majority of the respondents often used their mobile phone application and were satisfied with the attributes of their mobile phone.
\end{abstract}

\section{Keywords}

Brand-Choice, Customer Behaviour, Mobile Phone, Statistical Analysis Methodology

\section{Introduction}

According to Coghill [1], the development of mobile communication technology (wireless, internet, mobile phone, MP3 player, GPS navigation system) has been a long journey of innovation which is constantly evolving and updating because of consumers' changing needs and preferences. Among various contemporary mobile communication technologies, the mobile is regarded as "the most radiative domestic appliance ever invented." Statistics has shown that mobile phone 
subscribers were less a billion with most of, much of the subscription from the developed countries. However, it is estimated that for 2017, the number of mobile phone users is forecast to reach 4.77 billion. The number of mobile phone users in the world is however, expected to pass the 5 billion mark by the year 2019. In the year 2016 , it was estimated that approximately $70 \%$ of the population worldwide already owned a mobile phone

(https://www.statista.com/statistics/274774/forecast-of-mobile-phone-users-wor ldwide/). The wide spread of utilization of mobile phones in communication and information transfer has led to exponential improvement in mobile phone technology. To meet user's information needs, innovative features and applications are continuously being added to mobile phones to make them perform many more new functions. Consequently, the mobile phone which is essentially a communication device has undergone numerous transformations, making its functionalities transcend the traditional voice communication between two individuals [2] [3]. Mobile phone is no longer regarded as a luxury item or a status of symbol but rather a necessity in people's daily life [4].

Beyond voice, mobile phones fulfill users' needs by providing communication services and allowing transfer of information in the forms of text, graphics and voice; wireless internet services such as browsing and e-mail; and multimedia and entertainment services such as color screen, motion pictures, camera, games, music and other features [5]. Two decades ago, the telecommunications marked in Ghana was dominated and monopolized by Ghana Telecom (GT) presently known as Vodafone Ghana. Ghana Telecom was formerly known as Ghana Post and Telecommunication (GP \& T) was incorporated in 1994. Until 1992, cross boarder and internal cooperation between Ghana Telecom and Telecommunication providers elsewhere were all none existent. Typically, regulations prohibited foreign firms from entering the country's telecommunication market to compete with the domestic providers. Most of the traffic carried by Ghana Telecom was voice traffic; almost all of it was carried over wires, and customers were charged hefty premium to make long distance and international calls. Besides, the few telephone lines available were all centered in the regional capitals and metropolitan areas. Only the governmental ministries, universities, hospitals and few important government and private institutions had the opportunity of enjoying this facility. This facility was also accessible to the privilege in the society who will afford to pay for the services rendered.

The first cellular phone service Mobitel (now Tigo) was initiated in 1992 by Millicom Ghana limited. Next, it was Westel Spacefon (now MTN) operated by Scancom Ghana Limited joined Mobitel in 1994 in the provision of mobile telephone services. One-Touch (now Vodafone) operated by Ghana Telecom mobile telephone operator was the next competitor in the cellular phone market in the year 2000. A local cellular phone operator, Kasapa (now Expresso), followed. In May 2008, Globacom limited a Nigerian multinational telecommunication company acquired an operating license through its Glo mobile division in Gha- 
na. Between 1992 and the year 2001, mobile phone usage seemed limited to some categories of people in the country. These included businessmen, managers in reputed companies, government officials, diplomatic corps, wealthy individuals and some very important personalities. This was limited to the country's main cities. Eventually, due to the nationwide coverage of mobile phone service by providers, every category of people owns mobile phones, and even the less privileged from various villages also use mobile phone. It has helped bring about a source of employment to a section of the populace, and it has become fashionable to own a mobile phone. The acquisition of mobile phones by all has brought some challenges in such a way that people go to all extent to acquire them [6].

Dziwornu [7] stated that in Ghana, there is a considerable population of mobile phone users. Mobile service in Ghana has advanced to a stage where, in addition to traditional service such as voice call and short message service (SMS), most users can freely enjoy the latest technologies such as mobile internet, e-learning, banking and video conferencing. Consumer research has devoted little in understanding the relative factors underlying the mobile phone buying decision process. These factors may include conditions that affect the evolution of mobile phone market in general and individual consumers' motives. The mobile industry is one of the most dynamic industries that exist in the country today. This can be attributed to the constant change and competitiveness that characterizes the market. It is important that we consider the key consumer buying decision process and cast light on the factors that finally influence consumer choice between difference mobile phone brands. Unfortunately, only a few published academic researchers were focused on comparative studies. Despite the growing importance of mobile phone technology there has, to date, been relatively little research on consumers' evaluation of the factors that influence the choice of brands of mobile phone, particularly in the Ghanaian context.

The main objective of this article is to determine the influencing factors that determine the choice of a brand of mobile phone by considering the satisfaction levels among mobile phone users, and to determine whether there is association between a particular mobile phone brand and educational level and occupational level. The null hypotheses formulated for this article are:

$H_{0}$ : there is no association between a particular mobile phone brand usage and educational level;

$H_{1}$ : there is no association between a particular mobile phone brand usage and occupational status;

$H_{2}$ : there is no association between brand of mobile phone used and satisfaction level.

\section{Literature Review}

Access to mobile phones expands, development of organizations is straining to keep abreast of how these technologies are affecting both flows of information and best practice implementation of development projects. Practitioners already 
are leveraging these technologies of development projects. Practitioners already are leveraging these technologies around the world, using mobile phones for such value-added tasks as providing farmers with up-to-minute crop price information, linking rural health workers to medical doctors and providing financial services to the previously unbanked. But these and other programs often are implemented without a solid understanding of the user environment. The analysis from Audience Scapes Ghana 2009 survey provides a glimpse of that environment in Ghana [8]. However, despite the broad reach of mobile phones in Ghana, the survey indicated that voice calls remain the predominant function used by most people. Even the most popular non-voice functions SMS between users or from operators and third-party information services are not habitual activities for nearly two-thirds of mobile users.

There are many social and interpersonal factors that influence customers to decide about any product, which is so in the case of the mobile phone also. Consumer behaviour is affected by a lot of variables, ranging from personal motivations, needs, attitudes and values, personality characteristics, socio-economic and cultural background, age, sex, professional status to social influences of various kinds exerted by family, friends, colleagues and society [4] [9]. Consumer decision making process for a product is usually guided by already formed preference for a specific alternative [10] [11]. A consumer choice for a product, which is a bundle of attributes, is based on maximizing satisfaction to his budget constraints of available resources. The choice depends on whether the consumer is satisfied or dissatisfied with the product. Quite similarly, consumer choice can also be approached from the perspective of conscious and non-conscious choice [9]. Many choice situations occur outside of conscious awareness and with information search [12].

Several models have been developed to explain consumer purchasing behaviour. Engel, Blackwell and Miniard [13] proposed a model which view consumers purchase as a process that goes through a five steps problem solving process. However, Blackwell [9] argues that consumer research is primarily based on seven stages outlined below. The first stage; need recognition is when the consumer recognizes a problem or responds to a marketing promotion activity. The second stage is where the consumer searches for more useful information about various alternatives of products to satisfy his/her need. The information search can be internal or external. The third stage is where the consumer pays attention to the characteristics which are most relevant to their needs. The consumer usually uses attributes such as quality, size, quantity and price to judge a brand. The fourth stage is where the consumer purchases the products. The fifth stage is where the consumer begins to consume the product purchased. The sixth stage is where the consumer evaluates the consumption process. This process gives rise to satisfaction when the consumer expectations are lower than the perceived performance and vice versa. The final stage however, is where the satisfaction or dissatisfaction with the purchase made will then influence the 
consumers' decision process for the next similar purchase [9].

Understanding consumers' choice of product based upon it attributes help marketers to understand why some consumers have preferences for certain mobile phone brands. The Lancaster model of consumer demand by Hendler [14], also referred to as the product attributes model, was used to evaluate brand positioning. This model assumes that the consumer choice is based on the attributes of a brand. Each product is a bundle of attributes and that choice is based on maximizing satisfaction from the attributes subject to budget constraints. Both tangible and intangible attributes of a product are equally important in choosing a product. Liu [15] analyzes factors affecting the decision regarding brand in the mobile phone industry in Asia. It was found out that the choice of a mobile phone is characterised by two distinct attributes towards brand. He indicated that customers' choice of mobile phone brand is affected largely by new features more than size. This trend of choosing is phones with better capacity and larger screens.

\section{Research Methodology}

This section of the study outlines the methodology employed. Exploratory research was conducted using random target population for generalizability of the results. A structured questionnaire was prepared and self-administered to the respondents. The questionnaire was made up of 19 close ended questions used to collect opinions of respondents. The questionnaires were measured on a 5-point Likert scale ranging from 1 (strongly agree/always) to 5 (strongly disagree/never). The study population was made up of mobile phone owners within Anaji, New Takoradi, Tanokrom, Effia Kuma (including new site) and Windy Ridge where it is easy to assess respondents. Due to unavailability of the sampling frame and the impossibility of including every individual within the selected catchment area, a sample of 500 respondents were selected from which 478 of the administered questionnaires were retrieved. The remaining ones were discarded due to lack of response to a considerable number of items on the questionnaire and hence yielding a response rate of $96 \%$. This response rate was considered sufficient for statistical reliability and generalizability [16]. Data was analyzed using Minitab and SPSS, versions 17 and 20 respectively.

Chi-square test statistic and one sample t-test were used. The Chi-square test statistic was used to check the relationship between categorical variables whereas the $t$-test was used to determine whether a sample comes from a population with a specific mean.

$$
\chi^{2}=\sum_{i=1}^{r} \sum_{j=1}^{c} \frac{\left(O_{i j}-E_{i j}\right)}{E_{i j}}
$$

where

$$
\begin{aligned}
& \chi^{2}=\text { Chi-square } \\
& O_{i j}=\text { the observed frequency in the } i^{t h} \text { row and } j^{\text {th }} \text { column }
\end{aligned}
$$




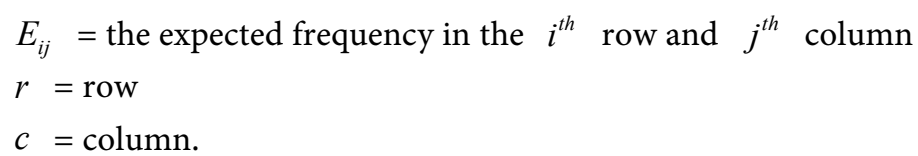

The statistic under the null hypothesis has an approximate chi-square distribution with the degrees of freedom given by $(r-1)(c-1)$. The chi-square test statistic is used because; the samples drawn from the population are approximately normally distributed, the samples drawn from different population are randomly independents and the samples drawn from the population have the same standard deviation. In reporting the conclusion, if the $p$-value calculated is less than the alpha value observed ( $p<\alpha$ ), then the result is statistically significant indicating that the researcher has enough evidence to reject the null hypothesis and conclude that the two variables are related. However, if the $p$-value calculated is greater than alpha value observed $(p>\alpha)$, then the researcher does not have enough evidence to reject the null hypothesis that is the researcher does not have enough evidence to conclude that two variables are related.

The one sample t-test is the same as the formula for determining $z$-score, except that we are subtracting the sample mean from the population mean using the estimated standard error of the mean instead of the standard deviation.

$$
t=\frac{\bar{x}-\Delta}{s / \sqrt{n}}
$$

where

$$
\begin{aligned}
& \bar{x}=\text { the sample mean } \\
& \Delta=\text { specified value to be tested } \\
& s=\text { sample standard deviation } \\
& n=\text { size of the sample. }
\end{aligned}
$$

The assumptions to apply the one sample t-test are: data are independent, data are collected randomly and data are approximately normally distributed. The values in the t-table are not actually listed by sample size but by degrees of freedom $(d f)$. The number of degrees of freedom for a problem involves the t-distribution for sample size $n-1$ for one-sample mean problem.

\section{Analysis of Results and Discussion}

The respondents varied on the preferred type of mobile phone brands, ranging from Nokia, Samsung, Infinix, Techno and others. The highest proportion of the respondents fell on Samsung. This accounted for $21 \%$ of the total respondents. This was followed by Infinix (18\%), Nokia (16\%), Techno (14\%) and the least among the preferred brand was others. This also accounted for $2 \%$ of the population (see Table 1). On the issue of reasons for the preferred choice, the sample was skewed towards popularity with $30 \%$ of the respondents being popularity and $21 \%$ were high quality and battery life. This was followed by more features (15\%), fashionable (13\%) and the least was fashionable (9\%). On the issue of major features respondents considered before the selection of a mobile brand saw varied responses. 
Table 1. Characteristics Respondents Consider when Purchasing a Mobile Phone.

\begin{tabular}{|c|c|c|}
\hline Variable & Count & Percent \\
\hline \multicolumn{3}{|l|}{ Mobile phone brands } \\
\hline Nokia & 74 & 16 \\
\hline Samsung & 102 & 21 \\
\hline LG & 30 & 6 \\
\hline HTC & 38 & 8 \\
\hline Blackberry & 27 & 6 \\
\hline iPhone & 45 & 9 \\
\hline Infix & 84 & 18 \\
\hline Techno & 69 & 14 \\
\hline Others & 9 & 2 \\
\hline \multicolumn{3}{|l|}{ Reasons for the choice } \\
\hline Affordability & 68 & 13 \\
\hline Fashionable & 41 & 9 \\
\hline More features & 70 & 15 \\
\hline Reliability & 58 & 12 \\
\hline High quality and battery life & 96 & 21 \\
\hline Popularity & 145 & 30 \\
\hline \multicolumn{3}{|c|}{ Major features considered before the selection of a mobile } \\
\hline Bluetooth & 40 & 8 \\
\hline Radio/FM & 15 & 3 \\
\hline Camera & 102 & 21 \\
\hline Touch screen & 86 & 18 \\
\hline Memory card slot & 25 & 5 \\
\hline Internet access & 160 & 34 \\
\hline Video/audio player & 50 & 11 \\
\hline \multicolumn{3}{|c|}{ Price of mobile phones in Ghana cedis } \\
\hline Below 100 & 8 & 2 \\
\hline $100-300$ & 120 & 25 \\
\hline $310-599$ & 196 & 41 \\
\hline $600-899$ & 74 & 16 \\
\hline $900-1000$ & 60 & 12 \\
\hline Above 1000 & 20 & 4 \\
\hline \multicolumn{3}{|l|}{ Distribution of mobile networks } \\
\hline MTN & 170 & 36 \\
\hline Vodafone & 146 & 30 \\
\hline Tigo & 50 & 10 \\
\hline Airtel & 75 & 16 \\
\hline Glo & 25 & 5 \\
\hline Expresso & 12 & 3 \\
\hline
\end{tabular}

$34 \%$ out of the total respondents indicated Internet access, followed by Camera (21\%), Touch screen (18\%), Video/Audio player (11\%) and the least was Radio/FM (3\%). 
When the price of mobile phone at which respondents would like to purchase was examined, $41 \%$ out of the total respondents indicated $\$ 310$ - 599, followed by $\$ 100$ - 300 (25\%), $\$ 600-899$ (16\%). $2 \%$ out of the total respondents however indicated below $\$ 100$. Respondents were lopsided toward the number of sim card slot to be considered when purchasing a mobile phone, with $68 \%$ of the respondents being one sim card slot and $28 \%$ were 2 sim card slots whilst $4 \%$ postulated more than 2 sim card slots. In terms of the distribution of mobile networks, 36\% of the respondents posited MTN, followed by Vodafone (30\%), Airtel (16\%), Tigo (10\%) and the others accounted for by $8 \%$ (see Table 1). A test of independence on several pairs of variables was employed using Pearson's chi-square test, likelihood ratio test and linear-by-linear test.

As pointed out by Agresti [17], the linear-by-linear test is used to compare observed results with expected results by determine if a difference between observed data and expected data is due to chance, or it is due to a relationship between the variables under study. It is more reliable when the values in some of the cells are small (see Tables 2-4).

\section{Test of Hypotheses}

Hypothesis 1

$H_{0}$ : there is no association between a particular mobile phone brand usage and educational level

$H_{1}$ : there is an association between a particular mobile phone brand usage and educational level

The result in Table 2, using linear by linear association at $5 \%$ significance

Table 2. Test of Independence of Mobile Phone Brand Usage and Educational Level.

\begin{tabular}{cccc}
\hline Characteristics & Value & Df & Assymp. Sig. (2-sided) \\
\hline Pearson Chi-square & 84.061 & 21 & 0.000 \\
Likelihood ratio & 49.241 & 21 & 0.000 \\
Linear-by-linear association & 0.168 & 1 & 0.682 \\
\hline
\end{tabular}

Table 3. Test of Independence of Mobile Phone Brand Usage and Occupational Status.

\begin{tabular}{cccc}
\hline Characteristics & Value & Df & Assymp. Sig. (2-sided) \\
\hline Pearson Chi-square & 52.812 & 21 & 0.000 \\
Likelihood ratio & 57.698 & 21 & 0.000 \\
Linear-by-linear association & 9.290 & 1 & 0.002 \\
\hline
\end{tabular}

Table 4. Chi-Square Test Statistic on Mobile Phone Brand Usage and Occupational Status.

\begin{tabular}{cccc}
\hline Characteristics & Value & Df & Assymp. Sig. (2-sided) \\
\hline Pearson Chi-square & 17.225 & 7 & 0.016 \\
Likelihood ratio & 17.841 & 7 & 0.013 \\
Linear-by-linear association & 9.290 & 1 & 0.860 \\
\hline
\end{tabular}


level, the p-value calculated of 0.682 is greater than the alpha value of 0.05 . Therefore, we fail to reject the null hypothesis $H_{0}$ and conclude that there is no association between mobile phone brands and educational level.

Hypothesis 2

$H_{0}$ : there is no association between mobile phone brand usage and occupational status

$H_{1}$ : there is an association between mobile phone brand usage and occupational status

Results in Table 3, show the $p$-value corresponding to the Pearson chi-square test, likelihood ration and linear-by-linear association test $(0.000 ; 0.000$ and 0.002 respectively) are all less than the alpha value of 0.05 , hence we reject the null hypothesis $\left(H_{0}\right)$ and conclude that there is an association between mobile phone brand usage and occupational level.

Hypothesis 3

$H_{0}$ : there is no association between brand of mobile phone used and satisfaction level

$H_{1}$ : there is an association between brand of mobile phone used and satisfaction level

According to the result of the data analysis presented on Table, using linearby-linear association at $5 \%$ significance level, the $p$-value calculated $(0.860)$ is greater than the alpha value (0.05). Therefore, we fail to reject the null hypothesis $\left(H_{0}\right)$ and conclude that there is no association between brand of mobile phone used and satisfaction level.

Hypothesis

$H_{0}$ : making and receiving calls, text messaging, instant messaging, browsing the internet, playing mobile games, camera and calendar are not sometimes used.

$H_{1}$ : making and receiving calls, text messaging, instant messaging, browsing the internet, playing mobile games, camera and calendar are sometimes used.

According to the result of the data analysis presented in Table 5 at $5 \%$ significant level, the $p$-value for the 7 functions (making and receiving calls, text messaging, instant messaging, browsing the internet, playing mobile games, camera and calendar) are all 0.000 which is less than the alpha value of 0.05 , with a test value of 3 . The test value of 3 was selected as a result of the scaling of $1-5$. (from strongly agree to strongly disagree)therefore, we reject null hypothesis $\left(H_{0}\right)$ and conclude that making and receiving calls, text messaging, instant messaging, browsing the internet, playing mobile games, camera and calendar are sometimes used. Since the test value 3 , does not fall between the confidence interval and t-values are negatives, we can further conclude that respondents always or most often used the above mentioned mobile phone application.

Hypothesis

$H_{0}$ : respondents are uncertain about their satisfaction level regarding the following attributes of their phone, high battery capacity, high quality, modern, reliability of reception, more feature. 
Table 5. One Sample Test of Means on the use of the Mobile Phone Application.

\begin{tabular}{|c|c|c|c|c|c|c|}
\hline \multirow{3}{*}{ Functions } & \multicolumn{6}{|c|}{ Test value $=3$} \\
\hline & \multirow[t]{2}{*}{$\mathrm{t}$} & \multirow[t]{2}{*}{ df } & \multirow[t]{2}{*}{ Sig. (2-tailed) } & \multirow{2}{*}{$\begin{array}{c}\text { Mean } \\
\text { difference }\end{array}$} & \multicolumn{2}{|c|}{$\begin{array}{l}95 \% \text { CI of the } \\
\text { difference }\end{array}$} \\
\hline & & & & & Lower & Upper \\
\hline Marketing and receiving calls & -35.191 & 478 & 0.000 & -1.790 & -1.89 & -1.69 \\
\hline Text messaging & -10.047 & 478 & 0.000 & -0.826 & -0.99 & -0.66 \\
\hline Instant messaging & -17.060 & 478 & 0.000 & -1.232 & -1.37 & -1.09 \\
\hline Browsing the internet & -16.108 & 478 & 0.000 & -1.232 & -1.38 & -1.08 \\
\hline Playing mobile games & -8.518 & 478 & 0.000 & -0.826 & -1.02 & -0.63 \\
\hline Camera & -13.227 & 478 & 0.000 & -0.971 & -1.12 & -0.83 \\
\hline Calendar & -7.758 & 478 & 0.000 & -0.710 & -0.89 & -0.53 \\
\hline
\end{tabular}

Table 6. One Sample Test of Means on the Satisfaction with Attributes of their Mobile Phones.

\begin{tabular}{|c|c|c|c|c|c|c|}
\hline \multirow{3}{*}{ Functions } & \multicolumn{6}{|c|}{ Test value $=3$} \\
\hline & \multirow[t]{2}{*}{$\mathrm{t}$} & \multirow[t]{2}{*}{ df } & \multirow{2}{*}{ Sig. (2-tailed) } & \multirow{2}{*}{$\begin{array}{c}\text { Mean } \\
\text { difference }\end{array}$} & \multicolumn{2}{|c|}{$\begin{array}{c}95 \% \mathrm{CI} \text { of the } \\
\text { difference }\end{array}$} \\
\hline & & & & & Lower & Upper \\
\hline High battery capacity & -16.487 & 478 & 0.000 & -1.34058 & -1.5014 & -1.1798 \\
\hline High quality & -25.653 & 478 & 0.000 & -1.31884 & -1.4205 & -1.2172 \\
\hline Modern & -16.758 & 478 & 0.000 & -1.15942 & -1.2962 & -1.0226 \\
\hline Reliability of reception & -20.397 & 478 & 0.000 & -1.26812 & -1.3911 & -1.1452 \\
\hline More features & -20.045 & 478 & 0.000 & -1.21014 & -1.3295 & -1.0908 \\
\hline
\end{tabular}

$H_{1}$ : respondents are not uncertain about their satisfaction level regarding the following attributes of their phone, high battery capacity, high quality, modern, reliability of reception, more feature.

The p-values for the functions (high battery capacity, high quality, modern, reliability of reception and more features) are 0.000 which is less than the alpha value of 0.05 . We therefore reject the null hypothesis $\left(H_{0}\right)$ and conclude that respondents are not uncertain about their satisfaction level regarding the following attributes of their phones; high battery capacity, high quality, modern, reliability of reception and more features. Since the test value (3) does not lie between the confidence interval and the t-values are negative, we can further conclude that majority of the respondents strongly agree or agree that they are satisfied with the attributes of their phones (see Table 6).

Hypothesis

$H_{0}$ : respondents are uncertain about the following contributions mobile phones make to people's lives, access to information, quick reference to information, communication and interpretation of information and improve rela- 
Table 7. One Sample Test of Means on the Contribution of Mobile Phones on People's lives.

\begin{tabular}{|c|c|c|c|c|}
\hline \multirow{3}{*}{ Functions } & \multicolumn{4}{|c|}{ Test value $=3$} \\
\hline & \multirow[t]{2}{*}{ df } & \multirow{2}{*}{$\begin{array}{c}\text { Sig. } \\
\text { (2-tailed) }\end{array}$} & \multirow{2}{*}{$\begin{array}{c}\text { Mean } \\
\text { difference }\end{array}$} & $\begin{array}{l}95 \% \mathrm{CI} \text { of the } \\
\text { difference }\end{array}$ \\
\hline & & & & Lower Upper \\
\hline Access to information & -21.084478 & 0.000 & -1.31884 & $-1.4430-1.1952$ \\
\hline As a quick reference to information & -18.058478 & 0.000 & -1.21014 & $-1.3427-1.0776$ \\
\hline $\begin{array}{l}\text { Enhanced communication and interpretation } \\
\text { of information }\end{array}$ & -19.895478 & 0.000 & -1.17391 & $-1.2906-1.0572$ \\
\hline $\begin{array}{c}\text { Improve relation among friends and social } \\
\text { ties }\end{array}$ & -18.741478 & 0.000 & -1.24638 & $-1.3779-1.1149$ \\
\hline
\end{tabular}

\section{tionship among friends.}

$H_{1}$ : respondents are not uncertain about the following contributions mobile phones make to people's lives; access to information, quick reference to information, communication and interpretation of information and improve relationship among friends.

From the result of the data analysis presented in Table 7, the p-value for the function: access to information; as a quick reference to information; enhanced communication and interpretation of information and improve relation among friends and social ties are: $0.000 ; 0.000 ; 0.000$ and 0.000 ; respectively. These p-values are less than the alpha-value of 0.05 . Therefore, we reject the null hypothesis $\left(H_{0}\right)$ and conclude that the respondents are not uncertain about the following contributions (access to information; as a quick reference to information; enhanced communication and interpretation of information and improve relation among friends and social ties) mobile phone makes to their lives. The test value of 3 does not fall between the confidence interval and the $t$-values are all negatives. Therefore, it can be inferred that majority of the respondents strongly agree to the fact that mobile phone make the above-mentioned contributions to their lives.

\section{Conclusions}

The most used mobile phone brand is Samsung which is closely followed by Infinix and Nokia. Given that the population of Anaji, New Takoradi, Tanokrom, Effia Kuma (including new site) and Windy Ridge is a small version of the population of Sekondi-Takoradi, it is likely that this result will be generally true of Sekondi-Takoradi, granted that the sample is representative of the 5-selected communities.

Popularity, high quality and battery life, more features, affordability (pricing) were major influential factors which were considered before the choice of mobile phone brand. These attributes must also be considered by dealer of mobile phones. 
It was also inferred that for the people of the 5 communities ((Anaji, New Takoradi, Tanokrom, Effia Kuma (including new site) and Windy Ridge)): there is no association between mobile phone brand used and educational level; there is an association between mobile phone brand used and occupational status; there is no association between brand of mobile phone used and performance; majority of the respondents agree that they are satisfied with the attributes of their mobile phones. In general, mobile phones facilities play useful role in the lives of respondents.

\section{References}

[1] Coghill, R. (2001) Inappropriate Measures. The Ecologist, 31, 28-29.

[2] Hakoama, M. and Hakoyama, S. (2011) The Impact of Cell Phone Use on Social Networking and Development among College Students. The AABSS Journal, 15, 120.

[3] Kushchu, I. (2007) Positive Contribution of Mobile Phones to Society. Mobile Government Consortium International.

[4] Walsh, S.P. and White, K.M. (2007) Me, My Mobile, and I: The Role of Self and Prototypical Identity Influences in the Prediction of Mobile Phone Behaviour. Journal of Applied Social Psychology, 37, 2405-2434. https://doi.org/10.1111/j.1559-1816.2007.00264.x

[5] Ling, C., Hwang, W. and Salvendy, G. (2005) A Survey of What Customers Want in a Cell Phone Design. Behaviour and Information Technology, 26, 149-163. https://doi.org/10.1080/01449290500128214

[6] Adjei, E.A. (2011) Mobile Phone: A Blessing or a Curse? Ghanaweb. https://www.ghanaweb.com/GhanaHomePage/features/Mobile-Phone-A-BlessingOr-A-Curse-212024

[7] Dziwornu, R.K. (2013) Factors Affecting Mobile Phone Purchase in Greater Accra Region of Ghana: A Binary Logit Model Approach. International Journal of Marketing Studies, 15, 151. https://doi.org/10.5539/ijms.v5n6p151

[8] InterMedia (2010) Mobile Phone Communication in Ghana. http://www.myGhanaonline.com

[9] Blackwell, R.J. (2006) Consumer Behaviour. 10th Edition, Harcourt College Publishers, South Western-Thomson Learning, Cincinnati.

[10] Moorthy, S., Ratchford, B. and Talukdar, D. (1997) Consumer Information Search Revisited. Journal of Consumer Research, 23, 263-277. https://doi.org/10.1086/209482

[11] Mowen, J.C. and Minor, M. (1998) Consumer Behavior. Prentice-Hall, Inc., Upper Saddle River.

[12] Kivetz, R. and Simonson, I. (2000) The Effects of Incomplete Information on Consumer Choice. Journal of Marketing Research, 37, 427-448.

https://doi.org/10.1509/jmkr.37.4.427.18796

[13] Engel, J.F., Blackwell, R.D. and Miniard, P.W. (1995) Consumer Behavior. 6th Edition, Dryden Press, Chicago, New York.

[14] Hendler, R. (1975) Lancaster New Approach to Consumer Demand and Its Limitations. The American Economic Review, 65, 194-199.

[15] Liu, C. (2002) The Effects of Promotional Activities on the Brand Decisions in the 
Cellular Telephone Industry. The Journal of Product and Brand Management, 11, 42-51. https://doi.org/10.1108/10610420210419540

[16] Tabachnick, B.G., Fidell, L.S. and Osterlind, S.J. (2001) Using Multivariate Statistics. Allyn and Bacon, Boston.

[17] Agresti, A. (1996) An Introduction to Categorical Data Analysis. Wiley \& Sons, New York.

Submit or recommend next manuscript to SCIRP and we will provide best service for you:

Accepting pre-submission inquiries through Email, Facebook, LinkedIn, Twitter, etc. A wide selection of journals (inclusive of 9 subjects, more than 200 journals)

Providing 24-hour high-quality service

User-friendly online submission system

Fair and swift peer-review system

Efficient typesetting and proofreading procedure

Display of the result of downloads and visits, as well as the number of cited articles Maximum dissemination of your research work

Submit your manuscript at: http://papersubmission.scirp.org/

Or contact ojs@scirp.org 